\title{
Unbalanced sex ratio and triploidy in the genus Cyclocephala (Coleoptera: Scarabaeoidea: Dynastidae) in the Lesser Antilles: An example of parthenogenesis on islands?
}

\author{
Bernard DUTRILLAUX, Dominique PLUOT-SigWALT and AnNe-Marie DUTRILLAUX
}

UMR 7205 CNRS/MNHN, OSEB, Département Systématique et Evolution, Muséum National d'Histoire Naturelle, CP39, 16, rue Buffon,75005 Paris, France; e-mails: bdutrill@mnhn.fr; dps@mnhn.fr; amdutril@mnhn.fr

\author{
Key words. Coleoptera, Scarabaeoidea, Dynastidae, Cyclocephala, sex ratio, triploidy, parthenogenesis, Lesser Antilles
}

\begin{abstract}
Sex ratio and chromosomes studies were performed on six of the seven species of genus Cyclocephala present in the Lesser Antilles. Most sex ratios based on light trapping are skewed, with a frequent, but not exclusive, strong excess of females. These unbalances vary from species to species and island to island for the same species. Comparing old (seventies) and recent captures, the imbalances seem to increase with time. All of the 72 karyotyped males were diploid: 20,XY. Of the 15 females studied, one (C. dominicensis) was triploid: 30,XXX, a condition that only occurs in parthenogenetic species of beetles. We conclude that parthenogenesis is progressively developing within different sexual populations of Cyclocephala in the Lesser Antilles, which accounts for the excess of females recorded there. We propose that preexisting recessive mutations are the cause and that island colonization, by preventing panmictic reproduction, favours the expression of these recessive mutations. This would account for the accelerated occurrence of new characters (speciation/sub-speciation process), including unusual modes of reproduction such as parthenogenesis, and that several genetically related populations express these characters independently on different islands.
\end{abstract}

\section{INTRODUCTION}

It is not exceptional to observe an imbalance in the sex ratio (number of males per 100 females) among adult beetles captured in the wild. This imbalance may have several origins, such as a non-synchronized maturation. For example, in Melolontha melolontha Linneaeus, 1758, males occur earlier than females in spring. Chronological differences also occur at dusk, when this species is swarming (Svestka, 2006). A difference in survival, generally longer in females than males, may also exist so that males predominate early and females late in the season. This introduces a bias which can be overcome by sampling at different times (Dutrillaux \& Dutrillaux, 2012). Males and females may also have a different behaviour and visit different biotopes or plants. For nocturnal species, such as those of Cyclocephala Latreille, 1829, a frequent bias in sex ratio is a consequence of their sex-dependent attraction to light traps. Thus, an apparent excess of males or females may not indicate the true sex ratio of a population. However, an unbalanced sex ratio, in particular a marked increase in the proportion of females, may indicate an interesting event, the development of parthenogenetic reproduction, which warrants further investigation. During the course of several sessions of light trapping in the Lesser Antilles over a period of ten years while studying chromosomes and genetics of the genus Cyclocephala (Dutrillaux et al., 2007b, Giannoulis et al., 2012) we recorded imbalances in its sex ratio. Interestingly, within a given species, the imbalance often varied from island to island, whereas both the mode and the periods over which they were captured were similar. Thus, the strong reduction in the sex ratio on some islands might indicate the occurrence of both parthenogenetic and sexual populations. Parthenogenesis tends to occur more frequently on islands than on continents (Suomalainen, 1962). An usual explanation is that it is easier for parthenogenetic than sexual females to colonize new territories. Parthenogenesis is difficult to demonstrate when it occurs within sexual populations because parthenogenetic females remain attractive and will mate with males. This generally does not affect their reproduction, but exceptionally, a non-reduced (diploid) oocyte may be fertilized, which introduces an additional haploid set of chromosomes from the spermatozoon. This is one explanation of the fact that parthenogenetic individuals are frequently triploid or polyploid. This occurs in weevils (Tomiuk \& Loeschcke, 1992) and is proposed for the grasshopper Saga pedo (Dutrillaux et al., 2009). About $95 \%$ of the parthenogenetic species of Coleoptera are polyploid (calculated from Smith \& Virkki, 1978 and Lachowska et al., 2008). Parthenogenetic reproduction side tracks meiosis: both chromosome segregation at anaphase I and genetic recombination do not occur or are modified (Hales et al., 2002).In sexual reproduction, odd ploidies $(3 n, 5 n \ldots)$ lead to a severe hypofertility by disturbing meiotic chromosome segregation. Thus, except for exceptional cases of pathology, triploidy in a female indicates it is parthenogenetic. Here, we report data on unbalanced sex ratios in species of Cyclocephala from Martinique, Dominica and Guadeloupe and the detection of a triploid female. The hypothesis that the association between parthenogenesis and insularity is because the latter facilitates colonization by unique females is challenged. 
TABLE 1. Places and dates on which the different species of Cyclocephala were caught by light trapping in this study.

\begin{tabular}{|c|c|c|c|}
\hline Species & Island & Localities & Dates \\
\hline C. tridentata & Guadeloupe & $\begin{array}{c}\text { Domaine Duclos }\left(16^{\circ} 12^{\prime} \mathrm{N}, 61^{\circ} 40^{\prime} \mathrm{W}\right) \\
\text { Deshayes/Cafféière }\left(16^{\circ} 20^{\prime} \mathrm{N}, 61^{\circ} 47^{\prime} \mathrm{W}\right) \\
\text { Matouba }\left(16^{\circ} 31^{\prime} \mathrm{N}, 61^{\circ} 42^{\prime} \mathrm{W}\right) \\
\text { Near Morne à Louis }\left(16^{\circ} 10^{\prime} \mathrm{N}, 61^{\circ} 45^{\prime} \mathrm{W}\right)\end{array}$ & $\begin{array}{c}\text { II/III 2007, XI/XII 2009, IV } 2011 \\
\text { III } 2007 \\
\text { XI } 1999 \\
\text { II/III 2007, XI/XII } 2009\end{array}$ \\
\hline C. dominicensis & Dominica & $\begin{array}{l}\text { Trafalgar }\left(15^{\circ} 20^{\prime} \mathrm{N}, 61^{\circ} 24^{\prime} \mathrm{W}\right) \\
\text { Laudat }\left(15^{\circ} 30^{\prime} \mathrm{N}, 61^{\circ} 23^{\prime} \mathrm{W}\right)\end{array}$ & $\begin{array}{l}\text { XII } 2009 \\
\text { II } 2005\end{array}$ \\
\hline C. annamariae & Martinique & $\begin{array}{c}\text { Le Prêcheur/La Mary }\left(14^{\circ} 50^{\prime} \mathrm{N}, 61^{\circ} 15^{\prime} \mathrm{W}\right) \\
\text { Ajoupa Bouillon }\left(14^{\circ} 49^{\prime} \mathrm{N}, 61^{\circ} 06^{\prime} \mathrm{W}\right) \\
\text { Gros Morne }\left(14^{\circ} 43^{\prime} \mathrm{N}, 61^{\circ} 01^{\prime} \mathrm{W}\right) \\
\text { Sainte Anne }\left(14^{\circ} 26^{\prime} \mathrm{N}, 60^{\circ} 53^{\prime} \mathrm{W}\right)\end{array}$ & $\begin{array}{l}\text { XI 2009, III } 2011 \\
\text { XI } 2009 \\
\text { II 2005, XI } 2009 \\
\text { II } 1998\end{array}$ \\
\hline C. insulicola & Guadeloupe & Near Morne à Louis $\left(16^{\circ} 10^{\prime} \mathrm{N}, 61^{\circ} 45^{\prime} \mathrm{W}\right)$ & XI/XII 1999, II/III 2007, XI/XII 2007, XI/XII 2009 \\
\hline C. $m$. rubiginosa & $\begin{array}{l}\text { Guadeloupe } \\
\text { Martinique }\end{array}$ & $\begin{array}{l}\text { Domaine Duclos }\left(16^{\circ} 12^{\prime} \mathrm{N}, 61^{\circ} 40^{\prime} \mathrm{W}\right) \\
\text { Near Morne à Louis }\left(16^{\circ} 10^{\prime} \mathrm{N}, 61^{\circ} 45^{\prime} \mathrm{W}\right) \\
\text { Le Prêcheur/La Mary }\left(14^{\circ} 50^{\prime} \mathrm{N}, 61^{\circ} 15^{\prime} \mathrm{W}\right)\end{array}$ & $\begin{array}{c}\text { II/III 2007, XI/XII 2009, IV } 2011 \\
\text { II/III 2007, I/XII } 2009 \\
\text { XI 2009, III } 2011\end{array}$ \\
\hline C. mafaffa grandis & Guadeloupe & $\begin{array}{l}\text { Near Morne à Louis }\left(16^{\circ} 10^{\prime} \mathrm{N}, 61^{\circ} 45^{\prime} \mathrm{W}\right) \\
\text { Domaine Duclos }\left(16^{\circ} 12^{\prime} \mathrm{N}, 61^{\circ} 40^{\prime} \mathrm{W}\right)\end{array}$ & $\begin{array}{c}\text { II/III 2007, XI/XII } 2009 \\
\text { II/III 2007, XI/XII 2009, IV } 2011\end{array}$ \\
\hline
\end{tabular}

\section{MATERIAL AND METHODS}

We studied four of the five species of Cyclocephala endemic to the Lesser Antilles: C. tridentata Fabricius, 1801; C. dominicensis Dutrillaux et al., 2013; C. annamariae Dutrillaux et al., 2013 and C. insulicola Arrow, 1937 and 2 endemic subspecies C. melanocephala rubiginosa Burmeister, 1847 and C. mafaffa grandis Burmeister, 1847. They were captured by light trapping from 1998 to 2011 (principally between 2007 and 2011) at the places and dates indicated in Table 1:

Some specimens of each species and from most places were kept alive for a few days in wet earth and fed on apple, and brought back to the laboratories of INRA (National Institute of Agronomical Research, domaine Duclos, Guadeloupe) or MNHN (Muséum National d'Histoire Naturelle, Paris), where they were used for chromosome studies according to our usual methods (Dutrillaux et al., 2010). Most specimens are conserved in our personal collections. For all species, the hypertrophy of the anterior tarsi in males was used as an unambiguous criterion for sex determination. Sex ratio deviation was evaluated by comparing the numbers of males and females recorded with the theoretical expectation of an equal number using $\chi^{2}$ tests.

Dry specimens in the F. Chalumeau collection preserved in the Institut National de la Recherche Agronomique (INRA) (Domaine Duclos, Guadeloupe) were also examined.

In order to examine the female genital tract and spermatheca anaesthezied females of C. m. rubiginosa from Guadeloupe and Martinique and $C$. tridenta were dissected in a saline solution. Once extricated, the spermatheca was put on a slide in a drop of solution $(0.88 \mathrm{M} \mathrm{KCl}$ in water). It was first examined under a microscope and presence or absence of spermatozoa noted; then, the spermatheca was dilacerated, fixed in a few drops of Carnoy I fixative, dried and stained by placing it in Giemsa (5\% in water) for $10 \mathrm{~min}$. The whole female genital tract was also examined after potassium hydroxide treatment and staining the cuticular intima with chlorazol black.

Chromosome nomenclature: We followed ISCN nomenclature (Harnden \& Klinger, 1985), which is widely used in animal cytogenetics.

\section{RESULTS}

\section{Sex ratio of specimens captured in the years 1998-2011}

The sex ratios of six species were determined, of which 5 occurred on only one island and one on two islands. Thus, we have the sex ratios for seven independent populations.

- C. mafaffa grandis: 38 specimens consisting of 20 males and 18 females, all captured on Guadeloupe near Morne à Louis and at domaine Duclos. Thus, its sex ratio does not differ from a $1 / 1$ distribution (Table 2).

- C. insulicola: of the 54 specimens, all captured near the Morne à Louis, only 13 are males and 41 females. Compared to a $1 / 1$ distribution, there is a very significant deficit of males $\left(\chi^{2}=14.5, \eta=1, P<0.001\right)$.

- C. m. rubiginosa: on Martinique, only 7 males were recorded among the 38 specimens caught, indicating a significant excess of females $\left(\chi^{2}=15.2, \eta=1, P<0.001\right)$; on Guadeloupe, no males were recorded among the 26 specimens caught, indicating a very significant excess of females $\left(\chi^{2}=26, \eta=1, P<0.001\right)$.

- C. annamariae: (Martinique): 113 specimens were caught of which 36 were males and 77 females were caught prior to 2011, indicating a significant excess of females $\left(\chi^{2}\right.$ $=14.88 \eta=1, P<0.001)$. In 2011, a more marked imbalance was recorded, with 66 males and 180 females $\left(\chi^{2}=\right.$ 131.2, $\eta=1, P<0.001)$.

- C. dominicensis: (Dominica): for the 35 specimens from Laudat, there was a slight but significant excess of females (24 versus 11 males, $\chi^{2}=4.83, \eta=1, P<0.04$ ). The small and not representative sample (11 specimens) from Trafalgar was used only for chromosome and genetic studies.

- C. tridentata (Guadeloupe): among 268 specimens (153 males versus 115 females) captured before 2011, there was a slight but significant excess of males $\left(\chi^{2}=5.38\right.$, $\eta=1, P<0.025)$. Similar results were recorded for sub- 
TABLE 2. Comparison of the sex ratios of the species of Cyclocephala occurring on the different islands in the Lesser Antilles based on recent catches by light trapping and of specimens in the Chalumeau collection that were collected in the 1970s, and the tendency and probability that there has been a decrease or increase in the sex ratio over time. NS - non significant.

\begin{tabular}{|c|c|c|c|c|c|c|c|c|}
\hline \multirow{2}{*}{ Species } & \multicolumn{3}{|c|}{ No. collected in the seventies } & \multicolumn{3}{|c|}{ No. collected recently $1998-2011$} & \multicolumn{2}{|c|}{ Sex ratio $(M: F)$} \\
\hline & Males & Females & Sex ratio & Males & Females & Sex ratio & Tendency & Probability \\
\hline C. mafaffa & 21 & 19 & 1.11 & 20 & 18 & 1.11 & stable & \\
\hline C. insulicola & 45 & 45 & 1 & 13 & 41 & 0.32 & decreasing & $<0.01$ \\
\hline \multicolumn{9}{|l|}{ C. $m$. rubiginosa } \\
\hline Union Island & 2 & 5 & & & & & & \\
\hline Grenade & 2 & 2 & & & & & & \\
\hline Dominica & 6 & 2 & & & & & & \\
\hline Marie Galante & 0 & 3 & & & & & & \\
\hline Guadeloupe & 9 & 56 & 0.16 & 0 & 24 & 0 & decreasing & N.S. \\
\hline Martinique & 2 & 1 & & 7 & 31 & 0.23 & & \\
\hline C. tridentata & 37 & 26 & 1.42 & 153 & 115 & 1.33 & stable & \\
\hline C. dominicensis & 20 & 7 & 2.86 & 11 & 24 & 0.46 & decreasing & $<0.005$ \\
\hline C. annamariae & 18 & 7 & 2.57 & 102 & 257 & 0.4 & decreasing & $<0.001$ \\
\hline
\end{tabular}

samples from various localities. An excess of males (66 males to 33 females, $\chi^{2}=11, \eta=1, P<0.001$ ) was again recorded in captures at domaine Duclos in 2011.

\section{Sex ratio in older series}

The comparison of our data with that obtained earlier may be of interest for indicating evolutionary trends. The collection of F. Chalumeau (INRA, Domaine Duclos) includes insects mainly captured between 1970 and 1973 . The results of the comparison with our data, mainly obtained after 2006, thus more than 30 years later, are summarized as follows (Table 2):

- C. mafaffa: its sex ratio is very similar in the old and recent series.

- C. insulicola: its sex ratio, which was 1:1 (45 males versus 45 females) in the old series, indicates a recent decrease in the proportion of males in this population.

- C. m. rubiginosa: a marked excess of females was recorded by Chalumeau (1983) on Guadeloupe, who caught 8 males and 71 females. The complete lack of males recorded by us on Guadeloupe between 2007 and 2011 also indicates a further decrease in the proportion of males in this population. On other islands, only a few specimens were recorded (Table 2), but there is no indication of an unbalanced sex ratio.

- C. annamariae and C. dominicensis: for both species, labelled $C$. tridentata and $C$. tridentata dominicensis in the old series, respectively, there is an excess of males, which is no longer the case. As this study indicates, there is now an excess of females.

- C. tridentata: in this study we recorded an excess of males as was recorded in the seventies.

Although there is often no information on how the insects in the old collections were captured, it is very likely that most of them were obtained using light traps because Cyclocephala species remain hidden in the ground during the day. They were captured at different periods of the year and at diverse places. This heterogeneity makes the comparison with our data somewhat hazardous. Nevertheless, it appears that the sex ratio either did not change, or tended to decrease but never increased, over the 30 year period.

\section{Chromosome studies and demonstration of a triploidy}

Until 2009, only males of the various species were analyzed. Spermatogonium karyotypes of the 72 males studied consisted of 20 chromosomes $(20, \mathrm{XY})$ in all species, as in most Dynastidae (Dutrillaux et al., 2007a). All chromosomes were meta- or sub-metacentric, except in C. tridentata and C. dominicensis, in which we found an inversion polymorphism, with a variable number of acrocentric chromosomes (Fig. 1a). After 2008, we also studied a few females using the technique described by Angus (1982) for studying mid gut cells: the one specimen of C. tridentata, four of $C$. annamariae and three of $C$. m. rubiginosa all had a 20,XX karyotype. In addition, we studied seven females of $C$. dominicensis: six had a 20, XX karyotype and one a 30,XXX karyotype (Fig. 1b, c). In the latter, only four metaphases were analyzed and all were triploid. To ensure that the triploidy was not limited to a small number of cells, we took advantage of the silver staining of nucleolar proteins (Howell \& Black, 1980). We showed that when the NOR (nucleolus organizer region) is located on the $\mathrm{X}$ chromosome, there is one large block of silver stained proteins in XY males and two smaller blocks in XX female interphase nuclei (Dutrillaux et al., 2007b). In species of Cyclocephala, the NOR is also on the X chromosome (Dutrillaux et al., 2007a). Thus, we silver stained the mid gut cells of one male, one diploid female and the triploid female (Fig. 2a-c). As expected, there was one, two or three silver protein blocks in the majority of cells of each specimen, respectively. This demonstrates that triploidy was not limited to a small number of cells, and also, that the three NORs are active in triploids. It is noteworthy that the total amount of silver stained proteins remains relatively constant, indicating that the expression is regulated in relation to the number of NORs, as already reported for Dynastes hercules Linnaeus, 1758 (Dutrillaux et al., 2007a). Compared to diploids, the triploid female does not have a particular phenotype. 


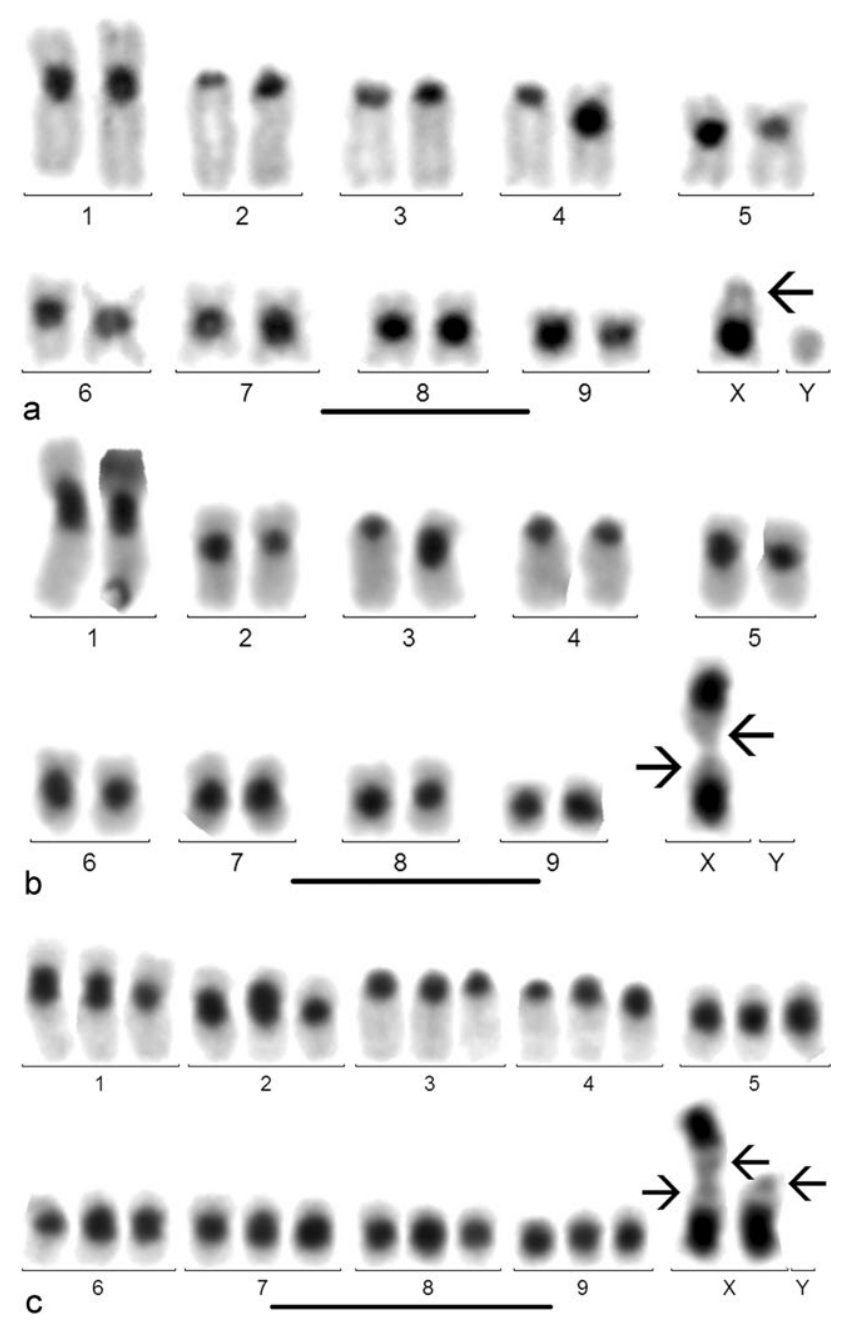

Fig. 1. C-banded karyotypes of Cyclocephala dominicensis. a - Male 20,XY karyotype displaying heterozygosity of chromosomes 4 . The NOR is located at the tip of the long arm of the $\mathrm{X}$ chromosome (arrow). b - Female 20,XX karyotype displaying heterozygosity of chromosomes 3 or 4 . Both Xs tend to be joined by their NORs (arrows), giving the appearance of a unique metacentric chromosome. c-Female triploid 30,XXX karyotype. Two of the three Xs are joined by their NORs. The non-associated X and the unique $\mathrm{X}$ of the male karyotype have the long arm on top, to show their similarity to those with the joined Xs. They usually separate in other metaphases.

\section{Female genital tracts}

We tried to determine if the genital tract of female C. $m$. rubiginosa, particularly the spermatheca and bursa copulatrix, had undergone some regression due to the absence or rarity of males. That is not the case. Comparison of the ectodermal genital apparatus of female C. m. rubiginosa from Guadeloupe and Martinique and female $C$. tridentata revealed no noticeable difference (Figs 3-5). The spermatheca of C. m. rubiginosa (females from Guadeloupe) not only shows no sign of regression but is even larger than that of other females and the spermathecal gland is remarkably long (1.5 cm) (Figs 6, 7). As for the bursa copulatrix, which receives the male spermathophore, it is neither modified nor reduced and almost identical to that of $C$. tridentata (Figs 4, 5). More importantly, the content of the

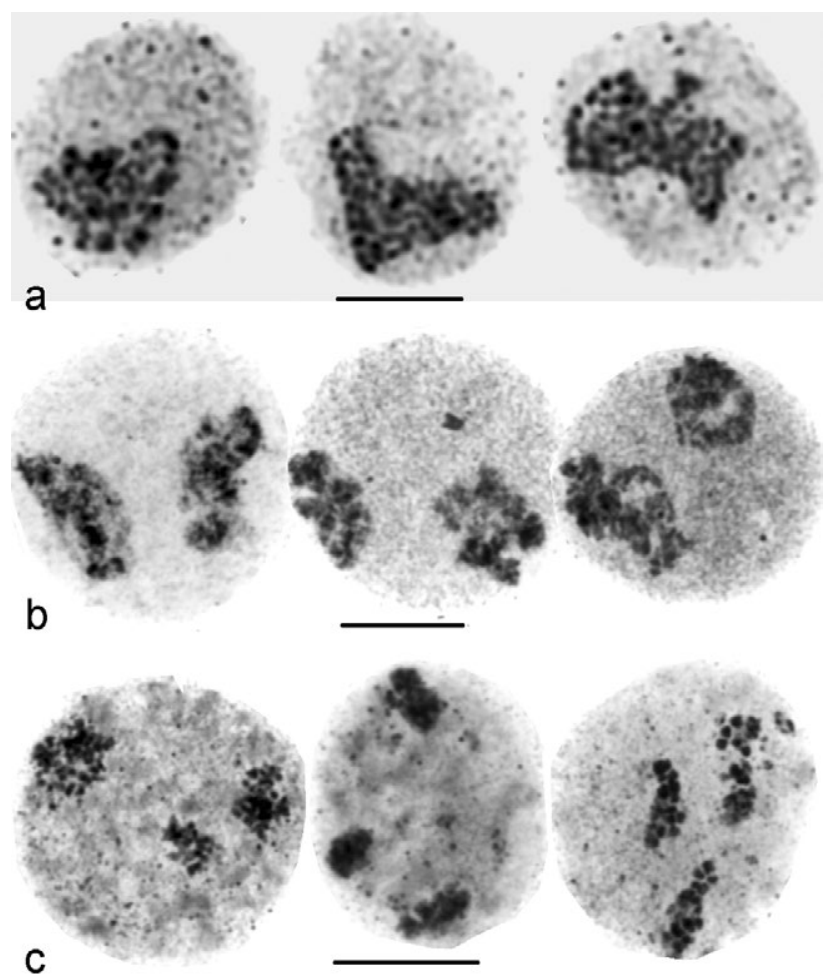

Fig. 2. Silver stained nuclei of mid gut cells of a diploid $X Y$ male (a), a diploid XX female (b) and triploid XXX female (c) with one, two and three blocks of nucleolar proteins corresponding to the number of NORs, respectively.

spermatheca of both of the females examined in vivo contained spermatozoa, but only an unusually small number.

\section{DISCUSSION}

The sex ratio analysis reported here, partially performed a posteriori and based on a single method of capture, i.e., light trapping, is not flawless. This introduces a bias, because attraction to light may be dependent on the sex, which limits its absolute value. However, most of this study involved three closely related species tridentata, dominicensis and annamariae, which were considered to be a single species until recently (Chalumeau, 1983; Dutrillaux et al., 2013), on three islands over the same period of time. The recorded excess of females of $C$. annamariae and $C$. dominicensis may indicate they are more attracted to light than males, but contrasts with the excess of males of $C$. tridentata. The excess of males of $C$. tridentata is present in both old and recent collections of this species from Guadeloupe. Thus, the larger number of females than of males of $C$. dominicensis and $C$. annamariae caught is assumed to indicate a rarity of males on Dominica and Martinique, respectively, unless there has been an unlikely change in sex-linked attraction to light. The complete lack of males of C. m. rubiginosa captured on Guadeloupe, whereas males were caught on Martinique over the same period, is puzzling, inasmuch as a few males are present in the older collections from Guadeloupe. This indicates there may have been a decrease in the sex ratio and perhaps an almost complete disappearance of males. For $C$. 

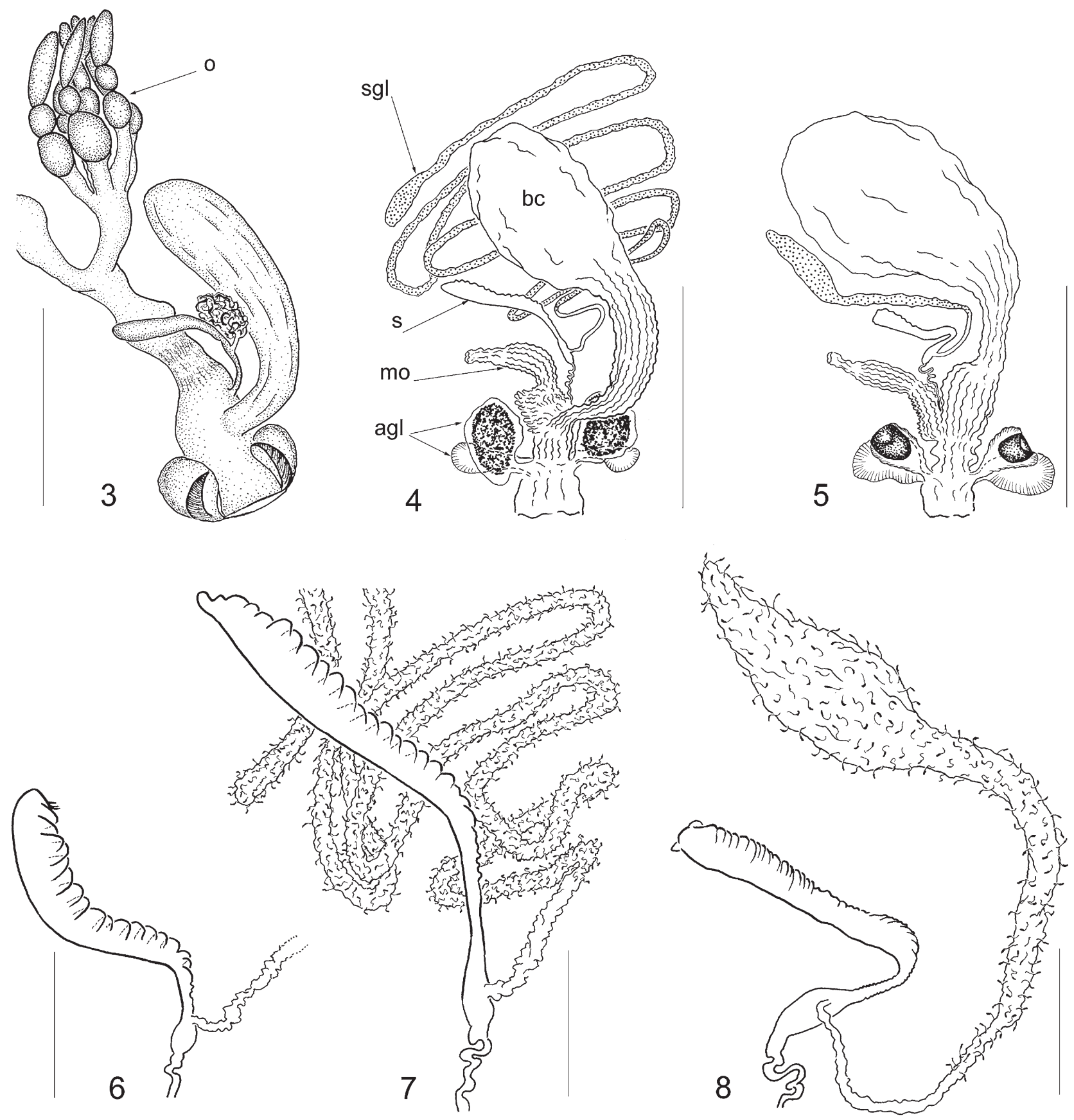

Figs 3-8. Female reproductive organs: 3 - C. melanoptera rubiginosa (Guadeloupe) observed in vivo; 4-5 - Ectodermal female genital tracts (cuticular intima); 4 - C. melanoptera rubiginosa (Guadeloupe); 5 - C. tridentata (Guadeloupe) ; 6-8: Spermatheca and its gland; 6 - C. melanoptera rubiginosa (Martinique); 7 - C. melanoptera rubiginosa (Guadeloupe); 8 - C. tridentata (Guadeloupe). Abreviations: agl - accessory gland; bc - bursa copulatrix; o - ovary; mo - median oviduct; s - spermatheca; sgl - spermathecal gland. Scale bar: $2 \mathrm{~mm}$.

dominicensis and $C$. annamariae, the normal sex ratio in the 2007-2011 series in contrast to the excess of males in the seventies is also puzzling. It may be an artifact, but almost all the data show the same tendency, which may indicate that males are more attracted than females to light, and a progressive decrease in the sex ratio, with differences between species and islands. As for the other species with an $\mathrm{XX} / \mathrm{XY}$ sex chromosome system, sexual reproduction should lead to a sex ratio of one. If there are no biases attributable to sampling, a low sex ratio may have different meanings. It may indicate the presence of sex lethal recessive genes located on the $\mathrm{X}$ chromosome, suppressing XY males, which would be highly deleterious for species survival. Another possible explanation is a change in the reproductive process, such as the set up of parthenogenesis. This mode of reproduction is not exceptional in insects, in particular in the coleopteran families Curculionidae, Chrysomelidae and Ptiliidae (Dybas, 1966; Robertson, 1966; Takenouchi, 1968; Smith \& Virkki, 1978; GomezZurita et al., 2006; Lachowska et al., 2008), but not yet 
reported in Scarabaeoidea. Parthenogenesis is not easy to demonstrate in natural populations. The lack of spermatozoa in the spermatheca could be a good criterion for indicating the absence of males, but it is not expected in a mixed sexual/non-sexual population, because parthenogenetic females occasionally mate with males. We looked for the presence of spermatozoa in the spermatheca of the two C. m. rubiginosa females captured in 2011 on Guadeloupe and found a small amount of spermatozoa in both. Thus, either there are males present but hardly detectable, or females copulate with males of other species. The finding of a triploid female could be important. Triploidy may be a rare consequence of abnormal gametogenesis or fertilization, but accidentally produced triploids cannot reproduce sexually, and thus, triploidy is extremely rare. As we only karyotyped 7 females of $C$. dominicensis, however, and found one triploid it is extremely unlikely that this triploid was found by chance and more likely that a proportion of the population is triploid. Unfortunately, we were not been able to go back to Dominica to collect a larger sample. It is well known that parthenogenesis is frequently associated with polyploidy. In Curculionidae, for instance, the karyotype of parthenogenetic species ranges from $3 \mathrm{n}$ to $10 \mathrm{n}$ (Takenouchi, 1968; Tomiuk \& Loeschke, 1992; Lachows$\mathrm{ka}$ et al., 2008). The origin of polyploidy in parthenotes is not univocal, but parthenogenetic females do copulate with males of either the same or closely related species. This could result in occasional fertilization involving a haploid set of chromosomes from the spermatozoon and a diploid ovum. The repetition of this process would generate progressive increases in the numbers of chromosomes from $3 n$ to $4 n, 5 n$ etc... In respect of the autosome/gonosome balance, only fertilizations by $\mathrm{X}$ carrier spermatozoa are effective. Thus, as long as males are present, the natural tendency of the progeny of parthenogenetic females would be to slowly increase from $2 n, X X$ to $3 n, X X X, 4 n, X X X X$ etc... Indeed, the association of a low sex ratio and triploidy strongly suggests the development of parthenogenesis within the sexual population of Cyclocephala species in the Lesser Antilles.

For other Neotropical regions, where the genus Cyclocephala occurs, there is very little data on its sex ratio. For the 211 species reported by Endrödi (1985) a lack of males is reported for three species: $C$. atriceps Casey, 1915 from Mexico, C. flora Arrow, 1911 from Brazil and Peru and C. vinosa Arrow, 1937 from Jamaica. A male for C. vinosa is described (Joly, 1998), which indicates an imbalance in its sex ratio. It is noteworthy that $C$. vinosa occurs in the Greater Antilles and the proportion of species endemic to the Antilles is about 1/20 (calculated from Endrödi, 1985). A superficial analysis like this does not have much value, but nevertheless does not contradict the present findings. If our interpretation of a progressive development of parthenogenesis in the Antilles is correct, the facilitated colonization of new territories by parthenogenetic females, frequently proposed to account for the increased incidence of parthenogenesis on islands, does not apply in this case. We propose the following alternative, but not exclusive, explanation. One of the characteristics of insular populations is their small size, especially just after colonization. The resulting lack of panmixis should increase homozygosity and result in the expression of recessive mutations. This could account for the increased incidence of morphological changes associated with the accelerated speciation/sub-speciation processes, which is also recorded on islands. The same genetic mechanism may also favour the acquisition of unusual modes of reproduction such as parthenogenesis if recessive mutations are the cause. To the best of our knowledge, there is no data on the genetics of parthenogenesis in Coleoptera, but some data exist in Drosophila melanogaster Meigen, 1830 (Diptera) in which two genetically determined mechanisms occur. The first one is a recessive mutation inducing male sterility (MS(3) $\mathrm{K} 81$ ), which conserves the capability of spermatozoa to activate gynogenetic development of eggs (Fuyama, 1986a). The second is governed by a few genes, presumably two, whose recessive mutations allow females to reproduce by gynogenesis (Fuyama, 1986b). As genes with similar properties are likely to exist in other insects, we propose that their recessive mutations may contribute to an increase in the occurrence of parthenogenesis in endogamic populations on islands. Such genetic determinism by preexisting recessive mutations would also account for the trends in parthenogenesis that occur in closely related species or genera, in Curculionidae and Chrysomelidae, as reported here in Cyclocephala.

\section{REFERENCES}

Angus R.B. 1982: Separation of two species standing as Helophorus aquaticus (L.) (Coleoptera, Hydrophilidae) by banded chromosome analysis. - Syst. Entomol. 7: 265-281.

Chalumeau F. 1983: Les coléoptères scarabaeides des Petites Antilles (Guadeloupe à Martinique). Lechevalier, Paris, 295 pp.

Dutrillaux A.-M. \& Dutrillaux B. 2012: Hannetons, le retour. - Le Coléoptériste 15: 111-115.

Dutrillaux A.-M., Mercier J. \& Dutrillaux B. 2007a: X-Y-autosome translocation, chromosome compaction, NOR expression and heterochromatin insulation in the scarabaeid beetle Dynastes hercules hercules. - Cytogenet. Genome Res. 116: 305-310.

DutrillauX A.-M., XIE H. \& Dutrillaux B. 2007b: High chromosomal polymorphism and heterozygosity in Cyclocephala tridentata from Guadeloupe: chromosome comparison with some other species of Dynastinae (Coleoptera: Scarabaeidae). - Cytogenet. Genome Res. 119: 248-254.

Dutrillaux A.-M., Lemonnier-Darcemont M., Darcemont C., KRPAC V. \& Fouchet P. 2009: Origin of the complex karyotype of the parthenogenetic grasshopper Saga pedo (Orthoptera: Tettigoniidae). - Eur. J. Entomol. 106: 477-483.

Dutrillaux A.-M., Pluot-Sigwalt D. \& Dutrillaux B. 2010: (Ovo-)viviparity in the darkling beetle, Alegoria castelnaui (Tenebrionidae: Ulomini), from Guadeloupe. - Eur. J. Entomol: 107: 481-485.

Dutrillaux B., Chalumeau F., Dutrillaux A.-M., Giannoulis T. \& MAMURIs Z. 2013: Séparation taxonomique en trois espèces au sein d'une population de Cyclocephala tridentata Fabricius (Coleoptera: Scarabaeidae: Dynastinae), sur la base de critères génétiques, chromosomiques et géographiques. - Ann. Soc. Entomol. Fr. (N.S.) 49: 61-67. 
DyBAs H.S. 1966: Evidence for parthenogenesis in the featherwing beetles, with a taxonomic review of a new genus and eight new species (Coleoptera: Ptilidae). — Fieldiana (Zool.) 51: 11-52.

Endrödi S. 1985: The Dynastinae of the World. Series Entomologica 28, Dr W. Junk, Dordrecht, 800 pp.

Fuyama Y. 1986a: Genetics of parthenogenesis in Drosophila melanogaster I. The modes of diploidization in the gynogenesis induced by a male sterile mutant MS (3) K81. — Genetics 112: 237-248.

Fuyama Y. 1986b: Genetics of parthenogenesis in Drosophila melanogaster II. Characterization of a gynogenetically reproducing strain. — Genetics 114: 495-509.

Giannoulis T., Dutrillaux A.-M., Stamatis C., Dutrillaux B. \& Mamuris Z. 2012: Cyclocephala (Coleoptera: Scarabaeidae: Dynastinae) evolution in Lesser West Indies indicates a Northward colonization by $C$. tridentata. - Bull. Entomol. Res. 102 325-332.

Gomez-Zurita J., Funk D.J. \& Vogler A.P. 2006: The evolution of unisexuality in Calligrapha leaf beetles: molecular and ecological insights on multiple origins via interspecific hybridization. Evolution 60: 328-347.

Hales F.D., Wilson A.C., Sloane M.A., Simon J.C., Le Galic J.F. \& SunNuCKS P. 2002: Lack of detectable genetic recombination on the $\mathrm{X}$ chromosome during the parthenogenetic production of female and male aphids. — Genet. Res. 79: 203-209.

Harnden D.G. \& KLINGer H.P. (eds) 1985: An international System for Human Cytogenetic Nomenclature. S. Karger AG, Basel, $118 \mathrm{pp}$.
Howell W.M. \& Black D.A. 1980: Controlled silver staining of nucleolus organizer regions with a protective colloidal developer: a one-step method. — Experientia 36: 1014-1015.

Joly L.J. 1998: Una especie nueva de Cyclocephala de la Republica Dominicana y descripcion del macho de Cyclocephala vinosa Arrow 1937 de Jamaica Coleoptera: Melolonthidae: Dynastinae: Cyclocephalini. Bol. Entomol. Venezol. 131: 45-55.

Lachowska D., Rozek M. \& Holecova M. 2008: New data on the cytology of parthenogenetic weevils (Coleoptera, Curculionidae). - Genetica 134: 235-242.

Robertson J.G. 1966: The chromosomes of bisexual and parthenogenetic species of Calligrapha (Coleoptera: Chrysomelidae) with notes on sex ratio, abundance and egg number. - Can. J. Cytol. 8: 695-732.

Smith S.G. \& VirkKi N. 1978: Coleoptera. In John B. (ed.): Animal Cytogenetics. Vol. 3. Insecta 5. Gegrüder Bornstraeger, Berlin, pp. 236-290.

Suomalainen E. 1962: Significance of parthenogenesis in the evolution of insects. - Annu. Rev. Entomol. 7: 349-366.

SvestKA M. 2006: Distributions of tribes of cockshafers of the genus Melolontha in forests of the Czeck Republic and the dependence of their swarming on temperature. - J. Forens. Sci. 52: 520-530.

TAKENOUCHI Y. 1968: A chromosome study on bisexual and parthenogenetic races of Scepticus insularis Roelofs (Curculionidae, Coleoptera). — Can. J. Genet. Cytol. 10: 945-950.

Tomiuk J. \& LoeschcKe V. 1992: Evolution of parthenogenesis in the Otiorhynchus scaber complex. - Heredity 68: 391-397.

Received November 29, 2013; revised and accepted March 6, 2014 Prepublished online May 6, 2014 